\title{
Short communication: Mid-infrared spectroscopy prediction of fine milk composition and technological properties in Italian Simmental
}

\author{
V. Bonfatti, ${ }^{* 1}$ L. Degano, † A. Menegoz, $\ddagger$ and P. Carnier* \\ *Department of Comparative Biomedicine and Food Science, BCA, University of Padova, Viale dell'Università 16, 35020, Legnaro, Italy \\ †Italian Simmental Cattle Breeders Association, via Nievo 19, 33100, Udine, Italy \\ †Friuli Venezia Giulia Milk Recording Agency, Via XXIX Ottobre 9/B, 33033, Codroipo, Italy
}

\section{ABSTRACT}

The objective of this study was to evaluate the ability of mid-infrared predictions of fine milk composition and technological traits to serve as a tool for large-scale phenotyping of the Italian Simmental population. Calibration equations accurately predicted the fatty acid profile of the milk, but we obtained moderate or poor accuracy for detailed protein composition, coagulation properties, curd yield and composition, lactoferrin, and concentration of major minerals. To evaluate the role of infrared predictions as indicator traits of fine milk composition in indirect selective breeding programs, the genetic parameters of the traits predicted using mid-infrared spectra need to be estimated.

Key words: infrared spectroscopy, fatty acids, protein composition, minerals

\section{Short Communication}

Mid-infrared (MIR) spectroscopy is a recognized tool for predicting novel milk traits at the population level for phenotyping and selective breeding purposes (De Marchi et al., 2014). To date, calibration equations have been developed using milk samples mostly from Holstein cows. Such models may not optimal when the aim is to obtain infrared predictions for samples from cows of other breeds (Eskildsen et al., 2014). For some traits, MIR predictions rely on indirect covariance structures with other traits, easily quantified by MIR, rather than on causal relationships with specific MIR absorption bands. One example is the prediction of individual fatty acid concentrations, which is based primarily on covariation between fatty acid and total fat content, and for which the contribution of absorption signals from specific fatty acids to the prediction is minimal (Eskildsen et al., 2014). When such covariance structures change across populations, calibration equations developed using milk samples from a specific

Received April 27, 2016.

Accepted June 21, 2016

${ }^{1}$ Corresponding author: valentina.bonfatti@unipd.it breed may lead to biased results and generate errors when applied to samples from other breeds.

Multibreed calibration sets are characterized by wide variability in milk composition relative to single breed sets and, generally, by high accuracy of calibration models. However, accuracy may be limited when predictions are obtained for a population of samples (e.g., single breed) that exhibit reduced variability compared with that of the calibration set. The objective of this study was to investigate the potential application of MIR spectroscopy to predict fine milk composition and technological traits in Italian Simmental. Calibration models developed in this study will serve as the basis for evaluating the role of predicted traits as indicators of fine milk composition in selective breeding in the Italian Simmental population.

The data were obtained by analyzing individual milk samples collected during morning milking from 1,230 Simmental cows in 21 herds located in northern Italy. Herd size ranged from 30 to 125 cows. All cows were fed TMR. Cows enrolled in the study were between 5 and 484 DIM, and their parity ranged from 1 to 9 . The final number of samples available per trait depended on budget constraints, analytical errors, and data editing (e.g., records with a trait value above 4 or below -4 standard deviations were excluded from the analysis).

Analysis of fatty acid composition was available for 1,040 samples. Milk fat was separated using an accelerated extraction method (Thermo Scientific Dionex ASE 350; Thermo Fisher Scientific, Rodano Milanese, Italy), according to the guidelines suggested in the Dionex Application Note 345 for milk and cream (Thermo Scientific Dionex, 2016). Gas chromatographic assessment of fatty acid concentrations in milk fat was performed as in Pellattiero et al. (2015).

The $\alpha_{\mathrm{S}_{1}} \mathrm{CN}, \alpha_{\mathrm{S} 2}-\mathrm{CN}, \beta-\mathrm{CN}, \gamma-\mathrm{CN}$, glycosylated and unglycosylated $\kappa-\mathrm{CN}, \beta-\mathrm{LG}$, and $\alpha$-LA contents of individual milk samples were measured using the reverse phase-HPLC method developed by Bonfatti et al. (2008) and were available for 1,137 samples. Measures of milk coagulation properties (MCP) were obtained as described by Dal Zotto et al. (2008), with minor modifications: $200 \mu \mathrm{L}$ of rennet (Naturen Standard 
215, Hansen 215 international milk clotting units/mL; Pacovis Amrein AG, Bern, Switzerland), diluted to $1.2 \%$ (vol/vol) in distilled water, was added to milk, and the total length of the analysis was extended to $60 \mathrm{~min}$. Curd yield and composition were assessed for 1,177 samples using a micro-cheesemaking procedure: $25 \mathrm{~mL}$ of milk was heated to $40^{\circ} \mathrm{C}$ for $15 \mathrm{~min}$, and 0.5 $\mathrm{mL}$ of the same diluted rennet used in the MCP analysis was added. After stirring, milk was kept at $40^{\circ} \mathrm{C}$ for $30 \mathrm{~min}$, and the curd was cut using a spatula and healed for $15 \mathrm{~min}$ at $40^{\circ} \mathrm{C}$. Samples were centrifuged for $20 \mathrm{~min}$ at $3,220 \times g$ at $10^{\circ} \mathrm{C}$. After whey removal, the micro-curds were used to assess DM content (method 926.08; AOAC International, 2003), protein content by Kjeldahl (method 2001.14; AOAC International, 2002), and fat content (using an accelerated extraction method, following Thermo Scientific Dionex, 2016). Lactoferrin was measured for 558 samples as in Soyeurt et al. (2007). Contents of $\mathrm{Ca}, \mathrm{P}, \mathrm{Mg}$ and $\mathrm{K}$ were measured for 689 samples by inductively coupled plasma optical emission spectrometry, using a Ciros Vision EOP (Spectro Analytical Instruments GmbH, Kleve, Germany) and the procedure proposed by Soyeurt et al. (2009).

Spectra were collected on all samples using a MilkoScan FT6000 (Foss Electric A/S, Hillerød, Denmark). Due to the interference of water absorption, the $\mathrm{O}-\mathrm{H}$ bending and $\mathrm{O}-\mathrm{H}$ stretching regions of the spectra (between 1,628 and 1,658 $\mathrm{cm}^{-1}$ and between $3,105 \mathrm{~cm}^{-1}$ and $3,444 \mathrm{~cm}^{-1}$, respectively) were removed (Hewavitharana and Brakel, 1997).

We developed preliminary calibration models using two-thirds of the samples and validated the models using the remaining one-third. Samples for calibration and validation were randomly selected. We tested 2 methods for outlier detection: (1) only samples exhibiting a global Mahalanobis distance (GH) from the population centroid $>3$ were considered outliers $(\mathrm{H}$ outliers) and discarded; (2) in addition to samples with $\mathrm{GH}>3$, samples for which the difference between the reference and the predicted value was $>2.5$ times the standard error of cross-validation were considered outliers (T outliers, Shenk and Westerhaus, 1995). In the latter case, we used 2 steps of outlier elimination.

We developed models by partial least squares regression with a 10-fold cross-validation, implemented in the R (R Development Core Team, 2013) PLS package (Mevik and Wehrens, 2007). Exclusion of $\mathrm{T}$ outliers ( 2 to $4 \%$ of the samples, depending on the trait) led to overestimated predictive ability in the equations and decreased the predictive ability in external validation (results not reported in tables). Conversely, when outlier identification was based exclusively on the GH distance ( $\mathrm{H}$ outliers), less than $0.5 \%$ of samples were excluded and the predictive ability in cross-validation was not significantly different from that in external validation (results not reported in tables).

For the final models, we used only GH distance for outlier identification. Models were developed on the totality of the data, without any further external validation procedure, by partial least squares regression with a 10-fold cross-validation (Mevik and Wehrens, 2007). We calculated the root mean squared error of prediction in cross-validation, the coefficient of determination between the predicted and measured values in cross-validation $\left(\mathbf{R}^{2} \mathbf{C V}\right)$, and the ratio of performance to deviation (RPD).

The results of the partial least squares models for individual fatty acids are shown in Table 1 . In general, when fatty acids were expressed on a milk basis, $\mathrm{R}_{\mathrm{CV}}^{2}$ values were high for all traits and were $>0.90$ for SFA, MUFA, short and medium-chain fatty acids, C12:0, C14:0, C16:0, $\Sigma$ unsaturated C18, $\Sigma$ C18:1, and C18:1n-7 cis-9. Other fatty acids, namely C14:1, C18:1 trans, C18:1n-7 trans-9, $\Sigma$ CLA, C18:2 cis-9,trans-11, and C18:3n-3, were poorly predicted by MIR spectroscopy $\left(\mathrm{R}_{\mathrm{CV}}^{2}<0.70\right)$. In general, $\mathrm{R}_{\mathrm{CV}}^{2}$ values were in agreement with those reported by Eskildsen et al. (2014) and slightly lower than those obtained by Soyeurt et al. (2011) and Ferrand-Calmels et al. (2014). All of these studies were conducted on different breeds to guarantee a wide variability in spectra. Because our study was aimed at providing a tool for large-scale phenotyping of the Simmental population, we developed calibration models using samples from Simmental cows, but they might be further improved by taking into account milk samples from other dairy breeds to increase the variability of the calibration set. The accuracy of the MIR predictions decreased when fatty acids were expressed on a fat basis, and was consistent with accuracy obtained by Rutten et al. (2009) and slightly worse than that estimated by Soyeurt et al. (2011) and Ferrand-Calmels et al. (2014). Two reasons for the low prediction accuracy obtained for fatty acid percentage relative to the one for fatty acid content may have been: (1) fatty acid measures as percentages in milk fat do not comply with Beer-Lambert's law (i.e., spectra absorbance is proportional to the content of a molecule in a sample and not to its relative quantity); and (2) the information used to predict fatty acids derives to a large extent from the correlation between fatty acids and total fat (Eskildsen et al., 2014), but when fatty acids are measured as percentages in milk fat, this correlation is much lower than the one between fatty acid content and total fat.

Parameters to evaluate the predictive performance of calibration models for milk technological properties, lactoferrin, and minerals are reported in Table 2. 
Prediction accuracy was satisfactory for $\mathrm{pH}$ and RCT $\left(\mathrm{R}_{\mathrm{CV}}^{2}\right.$ of 0.79 and 0.69 , respectively), but poor for other $\mathrm{MCP}$ traits $\left(\mathrm{R}_{\mathrm{CV}}^{2}<0.42\right)$. In the literature, calibration models for curd firmness at $30 \mathrm{~min}$ from rennet addition $\left(\mathbf{a}_{\mathbf{3 0}}\right)$ reached $\mathrm{R}_{\mathrm{CV}}^{2}$ values of 0.76 (De Marchi et al., 2013). Such inconsistency might be explained by the greater variability in MCP traits detected by those authors (e.g., the CV of $\mathrm{a}_{30}$ was almost 3 times that detected in our study), but also by the different equipment used when measuring MCP. The prediction accuracy of a model depends also on the accuracy of the reference analysis. Hence, instruments with low repeatability, reproducibility, or accuracy for a trait may lead to models with low accuracy. In agreement with our results, De Marchi et al. (2013) obtained unsatisfactory predictions for curd firmness at $60 \mathrm{~min}$ from rennet addition $\left(\mathbf{a}_{60}\right)$, and Cipolat-Gotet et al. (2012) detected large variability in curd firmness measured 45 min after rennet addition. Thus, it is reasonable to hypothesize that also $\mathrm{a}_{60}$ is measured with lower repeatability than $\mathrm{a}_{30}$.

A possible factor affecting the predictive ability of MCP traits might also be the correlation between MCP and total protein or $\mathrm{pH}$. Because MCP are linked to rheological properties, their prediction exploits the relationship between the coagulation behavior and the presence of specific chemical bonds. The relationship between MCP and chemical compounds might change across traits and populations. This may result in different predictive abilities for different MCP traits and may explain the inconsistency of results across studies.

Among curd yield traits, the prediction of dry matter curd yield showed the greatest $\mathrm{R}_{\mathrm{CV}}^{2}(0.85)$, followed by fat, raw, water, and protein curd yield, for which the $\mathrm{R}_{\mathrm{CV}}^{2}$ was 0.62 . Considering that curd yield partly depends on rheological property of milk, raw curd yield was predicted with relatively high accuracy $\left(\mathrm{R}_{\mathrm{CV}}^{2}=\right.$ $0.67)$. When, in preliminary analyses, we used a 2 -step elimination of outliers based on the difference between predicted and measured values, the $\mathrm{R}_{\mathrm{CV}}^{2}$ values of the calibration models were markedly higher, matching those obtained by Ferragina et al. (2013), who used the same outlier elimination method. Curd composition was predicted with poor accuracy, with $\mathrm{R}_{\mathrm{CV}}^{2}$ values ranging from 0.35 for fat content to 0.61 for DM content.

Models could only discriminate between high and low values of lactoferrin, and they were not sufficiently accurate to lead to precise quantification. More promising results have been obtained by Soyeurt et al. (2012), who reported an estimated $\mathrm{R}_{\mathrm{CV}}^{2}$ of 0.71 for lactoferrin prediction using a large number $(\mathrm{n}=2,499)$ of samples from 3 different countries. However, in that study, when

Table 1. Descriptive statistics and calibration performances for fatty acid contents in milk and concentrations in milk fat ${ }^{1}$

\begin{tabular}{|c|c|c|c|c|c|c|c|c|c|c|}
\hline \multirow[b]{2}{*}{ Trait } & \multicolumn{5}{|c|}{ Content in milk, $\mathrm{g} / \mathrm{dL}$} & \multicolumn{5}{|c|}{ Percentage in total milk fat, $\%$} \\
\hline & Mean & $\mathrm{SD}$ & $\mathrm{R}^{2} \mathrm{CV}$ & RMSEP & RPD & Mean & $\mathrm{SD}$ & $\mathrm{R}^{2} \mathrm{CV}$ & RMSEP & $\mathrm{RPD}$ \\
\hline SFA & 2.874 & 0.534 & 0.97 & 0.089 & 6.01 & 74.211 & 3.406 & 0.81 & 1.470 & 2.32 \\
\hline MUFA & 0.847 & 0.189 & 0.93 & 0.051 & 3.72 & 21.709 & 2.688 & 0.78 & 1.264 & 2.13 \\
\hline PUFA & 0.150 & 0.039 & 0.75 & 0.020 & 1.99 & 3.871 & 0.808 & 0.70 & 0.441 & 1.83 \\
\hline Short-chain fatty acids ${ }^{2}$ & 0.628 & 0.135 & 0.90 & 0.043 & 3.13 & 16.241 & 1.924 & 0.69 & 1.053 & 1.83 \\
\hline Medium-chain fatty acids ${ }^{2}$ & 1.928 & 0.381 & 0.95 & 0.089 & 4.28 & 49.784 & 3.903 & 0.75 & 1.952 & 2.00 \\
\hline Long-chain fatty acids ${ }^{2}$ & 0.255 & 0.087 & 0.77 & 0.041 & 2.09 & 6.584 & 1.827 & 0.72 & 0.951 & 1.92 \\
\hline$n-6$ & 0.081 & 0.025 & 0.75 & 0.012 & 2.00 & 2.112 & 0.567 & 0.71 & 0.305 & 1.86 \\
\hline$n-3$ & 0.021 & 0.007 & 0.72 & 0.004 & 1.90 & 0.552 & 0.166 & 0.64 & 0.098 & 1.70 \\
\hline C10:0 & 0.143 & 0.033 & 0.88 & 0.011 & 2.91 & 3.715 & 0.528 & 0.73 & 0.277 & 1.90 \\
\hline $\mathrm{C} 12: 0$ & 0.171 & 0.042 & 0.90 & 0.013 & 3.20 & 4.432 & 0.701 & 0.77 & 0.337 & 2.08 \\
\hline C14:0 & 0.523 & 0.103 & 0.90 & 0.033 & 3.10 & 13.552 & 1.288 & 0.66 & 0.742 & 1.74 \\
\hline $\mathrm{C} 16: 0$ & 1.297 & 0.269 & 0.92 & 0.080 & 3.37 & 33.440 & 3.019 & 0.70 & 1.637 & 1.84 \\
\hline C18:0 & 0.238 & 0.082 & 0.78 & 0.038 & 2.17 & 6.126 & 1.714 & 0.72 & 0.898 & 1.91 \\
\hline$\Sigma \mathrm{C} 14: 1$ & 0.042 & 0.014 & 0.64 & 0.008 & 1.66 & 1.085 & 0.302 & 0.47 & 0.215 & 1.40 \\
\hline$\Sigma \mathrm{C} 16: 1$ & 0.088 & 0.026 & 0.73 & 0.013 & 1.91 & 2.265 & 0.443 & 0.53 & 0.302 & 1.47 \\
\hline$\Sigma$ unsaturated C18 & 0.800 & 0.189 & 0.91 & 0.058 & 3.27 & 20.706 & 3.451 & 0.82 & 1.465 & 2.36 \\
\hline$\Sigma \mathrm{C} 18: 1$ & 0.669 & 0.163 & 0.90 & 0.051 & 3.19 & 17.309 & 3.014 & 0.81 & 1.284 & 2.35 \\
\hline$\Sigma \mathrm{C} 18: 1$ trans & 0.052 & 0.013 & 0.67 & 0.008 & 1.73 & 1.344 & 0.309 & 0.52 & 0.215 & 1.44 \\
\hline C18:1n-7 cis-9 & 0.585 & 0.150 & 0.90 & 0.048 & 3.12 & 15.106 & 2.817 & 0.81 & 1.179 & 2.39 \\
\hline C18:1n-7 trans-9 & 0.050 & 0.013 & 0.67 & 0.007 & 1.76 & 1.295 & 0.301 & 0.51 & 0.209 & 1.44 \\
\hline$\Sigma \mathrm{C} 18: 2$ & 0.111 & 0.029 & 0.76 & 0.014 & 2.05 & 2.884 & 0.614 & 0.70 & 0.335 & 1.83 \\
\hline $\mathrm{C} 18: 2 \mathrm{n}-6$ & 0.069 & 0.022 & 0.75 & 0.011 & 2.02 & 1.799 & 0.517 & 0.71 & 0.272 & 1.90 \\
\hline$\Sigma \mathrm{CLA}$ & 0.018 & 0.006 & 0.61 & 0.004 & 1.60 & 0.463 & 0.123 & 0.44 & 0.091 & 1.36 \\
\hline C18:2 cis-9,trans-11 (CLA) & 0.014 & 0.005 & 0.65 & 0.003 & 1.68 & 0.350 & 0.097 & 0.54 & 0.066 & 1.47 \\
\hline $\mathrm{C} 18: 3 n-3$ & 0.015 & 0.005 & 0.29 & 0.003 & 1.70 & 0.378 & 0.118 & 0.66 & 0.067 & 1.76 \\
\hline
\end{tabular}

${ }^{1} \mathrm{R}^{2} \mathrm{CV}=$ coefficient of determination of cross-validation; RMSEP $=$ root mean squared error of prediction; RPD = ratio of performance to deviation, calculated as the ratio of trait SD to RMSEP.

${ }^{2}$ Short-chain fatty acids $=$ fatty acids from $\mathrm{C} 4$ to $\mathrm{C} 10$; medium-chain fatty acids $=$ fatty acids from $\mathrm{C} 12$ to $\mathrm{C} 16$; long-chain fatty acids $=$ fatty acids from $\mathrm{C} 18$ to $\mathrm{C} 24$. 
the calibration was tested in external validation on Belgian samples only, the $\mathrm{R}^{2}$ was consistent with the estimate obtained in our study. Soyeurt et al. (2012) used samples from different countries and different breeds to maximize the variability in the calibration set. However, when the validation set included only samples from 1 country (i.e., when the variability in the validation set was lower than the one in the calibration set), the prediction accuracy decreased. The average lactoferrin content in our study was $128 \pm 96 \mathrm{mg} / \mathrm{L}$, a value lower than that obtained by Soyeurt et al. (2007, 2012). This might have negatively influenced the predictive ability of the model, because the performance of MIR spectroscopy in predicting a compound is largely dependent on its content in milk (Soyeurt et al., 2006; Rutten et al., 2009).

Values of $\mathrm{R}_{\mathrm{CV}}^{2}$ for minerals ranged between 0.41 and 0.48 Only Soyeurt et al. (2009) and Toffanin et al. (2015) investigated the potential of MIR spectroscopy to predict the major mineral content of cow milk. Soyeurt et al. (2009) obtained favorable results, reporting high accuracy for calcium and phosphorus $\left(\mathrm{R}_{\mathrm{CV}}^{2}\right.$ up to 0.87 and 0.85 , respectively) and reasonable accuracies for magnesium and potassium $\left(\mathrm{R}_{\mathrm{CV}}^{2}=0.65\right)$. However, in that study, samples used in calibration were chosen to maximize variability in spectra absorbances and pre- diction accuracy was expected to be greater than one achievable by random sampling.

Prediction models for protein fractions are presented in Table 3. We obtained good predictive ability for overall protein and casein content, for which the $\mathrm{R}_{\mathrm{CV}}^{2}$ of models was $>0.80$. Values of $\mathrm{R}_{\mathrm{CV}}^{2}$ for the content of the casein fractions ranged from 0.74 for $\alpha_{S_{1}}$ CN to 0.22 for unglycosylated $\kappa$-CN. Glycosylated $\kappa-\mathrm{CN}$ was also predicted with poor accuracy $\left(\mathrm{R}_{\mathrm{CV}}^{2}=0.46\right)$. For whey protein fractions, as well as for most caseins, the $\mathrm{R}_{\mathrm{CV}}^{2}$ showed that models could only discriminate between high and low protein values. These results are in agreement with Bonfatti et al. (2011), but are worse than those reported by Ferrand et al. (2012), who used HPLC coupled with mass spectrometry to assess the content of protein fractions. When protein fractions were expressed on a protein basis, results were even more unsatisfactory and consistent with those of Bonfatti et al. (2011) and Rutten et al. (2011). This was likely for the same reasons responsible for impaired prediction of fatty acids measured as percentages in milk fat. The prediction of protein fraction content relies indirectly on the relationship between the content of individual proteins and total milk protein. This might explain the marked difference in predictive ability between calibration equations for contents and percentages of protein

Table 2. Descriptive statistics and calibration performances for technological milk traits, lactoferrin, and mineral contents ${ }^{1}$

\begin{tabular}{|c|c|c|c|c|c|}
\hline Trait $^{2}$ & Mean & $\mathrm{SD}$ & $\mathrm{R}^{2} \mathrm{CV}$ & RMSEP & $\mathrm{RPD}$ \\
\hline $\mathrm{pH}$ & 6.74 & 0.08 & 0.79 & 0.04 & 2.16 \\
\hline $\mathrm{RCT}, \min$ & 18.51 & 5.81 & 0.69 & 3.22 & 1.81 \\
\hline $\mathrm{k}_{20}, \min$ & 7.11 & 0.85 & 0.42 & 0.64 & 1.32 \\
\hline $\mathrm{t}_{20}, \min$ & 25.58 & 6.78 & 0.55 & 4.50 & 1.51 \\
\hline $\mathrm{a}_{30}, \mathrm{~mm}$ & 34.32 & 6.50 & 0.32 & 5.31 & 1.22 \\
\hline $\mathrm{a}_{45}, \mathrm{~mm}$ & 34.88 & 4.16 & 0.20 & 3.67 & 1.13 \\
\hline $\mathrm{a}_{60}, \mathrm{~mm}$ & 32.99 & 4.13 & 0.21 & 3.63 & 1.14 \\
\hline \multicolumn{6}{|c|}{ Curd yield, $\mathrm{g} / 100 \mathrm{~g}$ of milk } \\
\hline Raw & 26.67 & 6.34 & 0.67 & 3.62 & 1.75 \\
\hline DM & 7.57 & 1.12 & 0.85 & 0.44 & 2.55 \\
\hline Water & 19.17 & 5.63 & 0.64 & 3.36 & 1.68 \\
\hline Protein & 2.89 & 0.44 & 0.62 & 0.27 & 1.64 \\
\hline Fat & 3.71 & 0.79 & 0.69 & 0.44 & 1.81 \\
\hline \multicolumn{6}{|c|}{ Curd composition, \% } \\
\hline Moisture & 71.02 & 4.15 & 0.61 & 2.58 & 1.60 \\
\hline Protein in DM & 38.50 & 5.08 & 0.43 & 3.83 & 1.33 \\
\hline Fat in DM & 48.43 & 6.32 & 0.35 & 5.04 & 1.25 \\
\hline Lactoferrin & 4.54 & 0.83 & 0.42 & 0.63 & 1.32 \\
\hline \multicolumn{6}{|l|}{ Minerals, mg/L } \\
\hline $\mathrm{Ca}$ & 1,211 & 186 & 0.48 & 131 & 1.42 \\
\hline $\mathrm{P}$ & 1,007 & 143 & 0.43 & 108 & 1.33 \\
\hline $\mathrm{Mg}$ & 101 & 17 & 0.46 & 12 & 1.37 \\
\hline $\mathrm{K}^{\circ}$ & 1,158 & 239 & 0.41 & 181 & 1.32 \\
\hline
\end{tabular}

${ }^{1} \mathrm{R}^{2} \mathrm{CV}=$ coefficient of determination of cross-validation; $\mathrm{RCT}=$ rennet coagulation time; RMSEP $=$ root mean squared error of prediction; $\mathrm{RPD}=$ ratio of performance to deviation, calculated as the ratio of traits deviation of a trait SD to RMSEP.

${ }^{2} \mathrm{RCT}=$ rennet coagulation time; $\mathrm{k}_{20}=$ curd firming time; $\mathrm{t}_{20}=$ time from rennet addition to $\mathrm{k}_{20} ; \mathrm{a}_{30}=$ curd firmness at $30 \mathrm{~min}$ from rennet addition; $\mathrm{a}_{45}=$ curd firmness at $45 \mathrm{~min}$ from rennet addition; $\mathrm{a}_{60}=$ curd firmness at $60 \mathrm{~min}$ from rennet addition. 
Table 3. Descriptive statistics and calibration performances for protein fraction contents in milk and concentrations in milk protein ${ }^{1}$

\begin{tabular}{|c|c|c|c|c|c|c|c|c|c|c|}
\hline Trait $^{2}$ & \multicolumn{5}{|c|}{ Content in milk, $\mathrm{g} / \mathrm{L}$} & \multicolumn{5}{|c|}{ Percentage in milk protein, $\%$} \\
\hline Protein & 37.09 & 3.83 & 0.81 & 1.66 & 2.31 & & & & & \\
\hline$\alpha_{S_{1}-C N}$ & 13.48 & 1.42 & 0.74 & 0.72 & 1.98 & 36.42 & 2.26 & 0.26 & 1.95 & 1.16 \\
\hline$\alpha_{\mathrm{S}_{2}-\mathrm{CN}}$ & 4.17 & 0.62 & 0.49 & 0.44 & 1.42 & 11.23 & 1.26 & 0.28 & 1.07 & 1.18 \\
\hline$\beta-\mathrm{CN}$ & 9.77 & 1.84 & 0.58 & 1.13 & 1.63 & 26.24 & 3.61 & 0.43 & 2.72 & 1.33 \\
\hline Glycosylated к-CN & 1.69 & 0.48 & 0.46 & 0.35 & 1.37 & 4.53 & 1.10 & 0.38 & 0.87 & 1.26 \\
\hline Unglycosylated $\kappa-\mathrm{CN}$ & 1.88 & 0.42 & 0.22 & 0.37 & 1.14 & 5.08 & 1.05 & 0.21 & 0.92 & 1.14 \\
\hline Whey protein & 5.44 & 0.79 & 0.53 & 0.54 & 1.48 & & & & & \\
\hline$\alpha-\mathrm{LA}$ & 1.33 & 0.24 & 0.24 & 0.21 & 1.16 & 3.62 & 0.65 & 0.27 & 0.56 & 1.17 \\
\hline$\beta-\mathrm{LG}$ & 4.10 & 0.71 & 0.48 & 0.51 & 1.41 & 11.07 & 1.66 & 0.40 & 1.29 & 1.28 \\
\hline
\end{tabular}

${ }^{1} \mathrm{R}^{2} \mathrm{CV}=$ coefficient of determination of cross-validation; RMSEP $=$ root mean squared error of prediction; RPD = ratio of performance to deviation, calculated as the ratio of trait SD to RMSEP.

${ }^{2}$ Protein $=$ casein + whey protein; casein $=\alpha_{\mathrm{S}^{-}} \mathrm{CN}+\alpha_{\mathrm{S}^{2}} \mathrm{CN}+\beta-\mathrm{CN}+\gamma-\mathrm{CN}+\kappa-\mathrm{CN} ; \kappa-\mathrm{CN}=$ glycosylated $\kappa$-CN + unglycosylated $\kappa$-CN; whey protein $=\alpha$-LA $+\beta-\mathrm{LG}$.

fractions and the very poor $\mathrm{R}_{\mathrm{CV}}^{2}$ obtained for minor fractions, in analogy with fatty acid contents, which are seemingly predicted indirectly from total fat content (Eskildsen et al., 2014).

This study confirmed that MIR can predict several nutritional and technological milk traits, but in general, we obtained only moderate accuracy in calibration models. Traits predicted with poor accuracy might benefit from the use of other techniques for spectra acquisition, such as dried film measurement instead of liquid milk measurement, as demonstrated by Afseth et al. (2010). However, the dried film approach has not yet been implemented for routine milk analysis.

According to Soyeurt et al. (2011), equations with $\mathrm{R}_{\mathrm{CV}}^{2}>0.95$ are useful in milk payment systems, and equations with $\mathrm{R}_{\mathrm{CV}}^{2}>0.75$ can be exploited in animal breeding programs. As described by Minasny and McBratney (2013) and confirmed by our data (Figure 1), for a normally distributed variable and a large sample size, the relationship between $R P D$ and $R_{C V}^{2}$ is RPD $=\left(1-\mathrm{R}_{\mathrm{CV}}^{2}\right)^{-0.5}$. When $\mathrm{R}_{\mathrm{CV}}^{2}=0.75, \mathrm{RPD}=2$, which is the threshold upon which a calibration model is arbitrarily considered to have good predictive ability (Minasny and McBratney, 2013). Values of $\mathrm{R}_{\mathrm{CV}}^{2}$ and $\mathrm{RPD}$ depend on the phenotypic correlation between the measured traits and the infrared predictions. In selective breeding, however, the usefulness of calibration models depends on the genetic gain achievable for a trait using predictions in place of measures. As such, gain is affected by genetic variability in the measured traits and by genetic correlation between the measured traits and their predictions; estimates of genetic parameters for infrared predictions are necessary to evaluate the usefulness of calibration models in breeding programs as a replacement for gold standard methods of phenotyping. In addition, for the traits investigated in this study, the usefulness of calibration models depends on the additional information provided by the spectra, independent of the one exploited in the prediction of milk fat or protein. Calibration models accurately predict milk fat and protein contents. If a trait to be predicted is correlated with milk fat or protein content, a calibration model for that trait may exhibit satisfactory predictive performance even when spectra do not provide independent information for the trait. However, such a model might generate biased predictions when

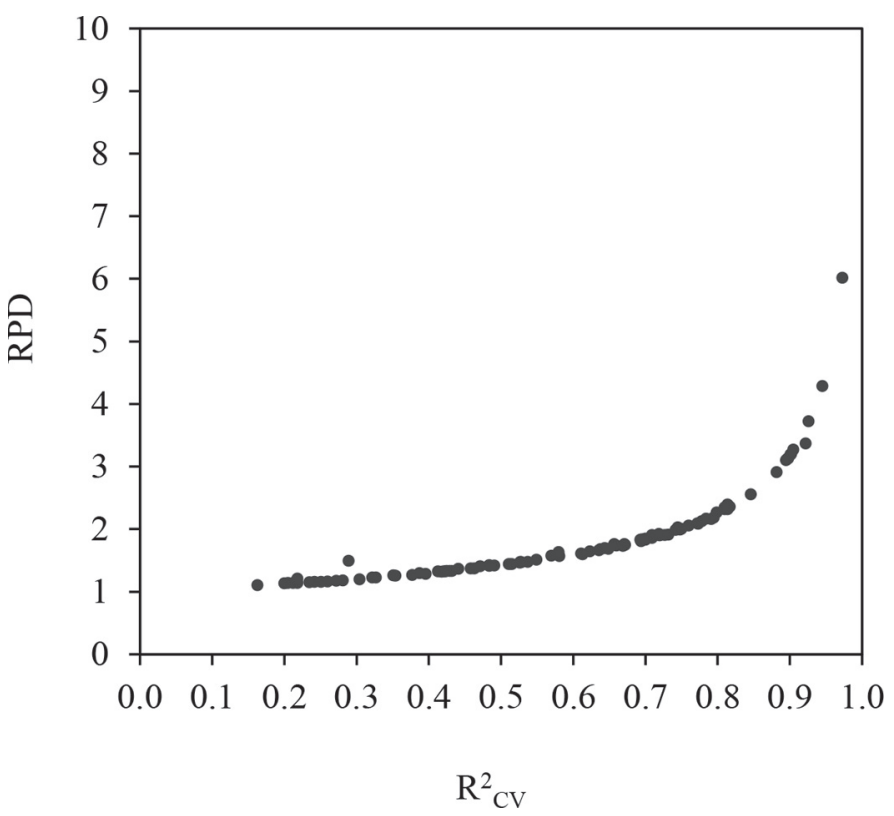

Figure 1. The relationship between the coefficient of determination in cross-validation $\left(\mathrm{R}_{\mathrm{CV}}^{2}\right)$ and the ratio of performance to deviation (RPD). 
it is used in populations for which the correlation between the trait and milk fat or protein is different (Eskildsen et al., 2014). Theoretically, if protein fractions were indirectly predicted by MIR exclusively as a consequence of their correlation with total protein, selective breeding for total protein would produce the same response for protein fractions as that provided by selective breeding for the MIR-predicted content of protein fractions. To evaluate the usefulness of calibration equations for selective breeding purposes, the genetic correlation between the newly predicted variables and milk fat or protein content need to be estimated.

\section{ACKNOWLEDGMENTS}

Financial support for this study was provided by the University of Padova (Progetto di Ateneo 2012-MilCo, CPDA122982).

\section{REFERENCES}

Afseth, N. K., H. Martens, A. Randby, L. Gidskehaug, B. Narum, K. Jørgensen, S. Lien, and A. Kohler. 2010. Predicting the fatty acid composition of milk: A comparison of two Fourier transform infrared sampling techniques. Appl. Spectrosc. 64:700-707.

AOAC International. 2002. Official Methods of Analysis. 16th ed. AOAC International, Washington, DC.

AOAC International. 2003. Official Methods of Analysis. 17th ed. AOAC International, Washington, DC.

Bonfatti, V., G. Di Martino, and P. Carnier. 2011. Effectiveness of mid-infrared spectroscopy for the prediction of detailed protein composition and contents of protein genetic variants of individual milk of Simmental cows. J. Dairy Sci. 94:5776-5785.

Bonfatti, V., L. Grigoletto, A. Cecchinato, L. Gallo, and P. Carnier. 2008. Validation of a new reversed-phase high-performance liquid chromatography method for separation and identification of bovine milk protein genetic variants. J. Chromatogr. A 1195:101-106.

Cipolat-Gotet, C., A. Cecchinato, M. De Marchi, M. Penasa, and G. Bittante. 2012. Comparison between mechanical and near-infrared methods for assessing coagulation properties of bovine milk. J. Dairy Sci. 95:6806-6819.

Dal Zotto, R., M. De Marchi, A. Cecchinato, M. Penasa, M. Cassandro, P. Carnier, L. Gallo, and G. Bittante. 2008. Reproducibility and repeatability of measures of milk coagulation properties and predictive ability of mid-infrared reflectance spectroscopy. J. Dairy Sci. 91:4103-4112.

De Marchi, M., V. Toffanin, M. Cassandro, and M. Penasa. 2013. Prediction of coagulating and noncoagulating milk samples using mid-infrared spectroscopy. J. Dairy Sci. 96:4707-4715.

De Marchi, M., V. Toffanin, M. Cassandro, and M. Penasa. 2014. Midinfrared spectroscopy as phenotyping tool for milk traits. J. Dairy Sci. 97:1171-1186.

Eskildsen, C. E., M. A. Rasmussen, S. B. Engelsen, L. B. Larsen, N. A. Poulsen, and T. Skov. 2014. Quantification of individual fatty acids in bovine milk by infrared spectroscopy and chemometrics: Understanding predictions of highly collinear reference variables. J. Dairy Sci. 97:7940-7951.

Ferragina, A., C. Cipolat-Gotet, A. Cecchinato, and G. Bittante. 2013 The use of Fourier-transform infrared spectroscopy to predict cheese yield and nutrient recovery or whey loss traits from unprocessed bovine milk samples. J. Dairy Sci. 96:7980-7990.
Ferrand, M., G. Miranda, H. Larroque, O. Leray, S. Guisnel, F. Lahalle, M. Brochard, and P. Martin. 2012. Determination of protein composition in milk by mid-infrared spectrometry. Pages $1-5$ in Proc. 38th Int. Comm. Anim. Rec. Ann. Meet. Cork. ICAR, Rome, Italy.

Ferrand-Calmels, M., I. Palhière, M. Brochard, O. Leray, J. M. Astruc, M. R. Aurel, S. Barbey, F. Bouvier, P. Brunschwig, H. Caillat, M. Douguet, F. Faucon-Lahalle, M. Gelé, G. Thomas, J. M. Trommenschlager, and H. Larroque. 2014. Prediction of fatty acid profiles in cow, ewe, and goat milk by mid-infrared spectrometry. J. Dairy Sci. 97:17-35.

Hewavitharana, A. K., and B. V. Brakel. 1997. Fourier transform infrared spectrometric method for rapid determination of casein in raw milk. Analyst (Lond.) 122:701-704.

Mevik, B. H., and R. Wehrens. 2007. The PLS package: Principal component and partial least squares regression in R. J. Stat. Softw. 18:1-24.

Minasny, B., and A. McBratney. 2013. Why you don't need to use RPD. Pedometron 33:14-15.

Pellattiero, E., A. Cecchinato, F. Tagliapietra, S. Schiavon, and G. Bittante. 2015. The use of 2-dimensional gas chromatography to investigate the effect of rumen-protected conjugated linoleic acid, breed, and lactation stage on the fatty acid profile of sheep milk. J. Dairy Sci. 98:2088-2102.

R Development Core Team. 2013. R: A Language and Environment for Statistical Computing. R Foundation for Statistical Computing, Vienna, Austria.

Rutten, M. J. M., H. Bovenhuis, J. M. L. Heck, and J. A. M. van Arendonk. 2011. Predicting bovine milk protein composition based on Fourier transform infrared spectra. J. Dairy Sci. 94:5683-5690.

Rutten, M. J. M., H. Bovenhuis, K. A. Hettinga, H. J. F. van Valenberg, and J. A. M. van Arendonk. 2009. Predicting bovine milk fat composition using infrared spectroscopy based on milk samples collected in winter and summer. J. Dairy Sci. 92:6202-6209.

Shenk, J. S., and M. O. Westerhaus. 1995. Forage analysis by near infrared spectroscopy. Pages 111-120 in Forages. Vol. II. The Science of Grassland Agriculture. 5th ed. R. F. Barnes, D. A. Miller, and C. J. Nelson, ed. Iowa State University Press, Ames.

Soyeurt, H., C. Bastin, F. G. Colinet, V. M.-R. Arnould, D. P. Berry, E. Wall, F. Dehareng, H. N. Nguyen, P. Dardenne, J. Schefers, J. Vandenplas, K. Weigel, M. Coffey, L. Théron, J. Detilleux, E. Reding, N. Gengler, and S. McParland. 2012. Mid-infrared prediction of lactoferrin content in bovine milk: Potential indicator of mastitis. Animal 6:1830-1838.

Soyeurt, H., D. Bruwier, J.-M. Romnee, N. Gengler, C. Bertozzi, D. Veselko, and P. Dardenne. 2009. Potential estimation of major mineral contents in cow milk using mid-infrared spectrometry. J. Dairy Sci. 92:2444-2454.

Soyeurt, H., F. G. Colinet, V. M.-R. Arnould, P. Dardenne, C. Bertozzi, R. Renaville, D. Portetelle, and N. Gengler. 2007. Genetic variability of lactoferrin content estimated by mid-infrared spectrometry in bovine milk. J. Dairy Sci. 90:4443-4450.

Soyeurt, H., P. Dardenne, F. Dehareng, G. Lognay, D. Veselko, M. Marlier, C. Bertozzi, P. Mayeres, and N. Gengler. 2006. Estimating fatty acid content in cow milk using mid-infrared spectrometry. J. Dairy Sci. 89:3690-3695.

Soyeurt, H., F. Dehareng, N. Gengler, S. McParland, E. Wall, D. P. Berry, M. Coffey, and P. Dardenne. 2011. Mid-infrared prediction of bovine milk fatty acids across multiple breeds, production systems, and countries. J. Dairy Sci. 94:1657-1667.

Thermo Scientific Dionex. 2016. All Application Notes, Updates, and Briefs. Accessed Jul. 22, 2016. http://www.dionex.com/en-us/ documents/application-notes-updates/lp-84398.html.

Toffanin, V., M. De Marchi, N. Lopez-Villalobos, and M. Cassandro. 2015. Effectiveness of mid-infrared spectroscopy for prediction of the contents of calcium and phosphorus, and titratable acidity of milk and their relationship with milk quality and coagulation properties. Int. Dairy J. 41:68-73. 